Nina Perger

\title{
LGBTIQ+ Youth and Experiences with Violence in Education
}

Keywords: LGBTIQ+, education, violence, power relations

DOI: $10.4312 /$ ars.12.1.88-103

\section{Introduction}

Research shows that young gays, lesbians, bisexuals, transgender, intersex and queer people (LGBTIQ+) experience various forms of violence and/or discrimination in various settings of their everyday life, including education. Such experiences are often analysed within the frame of the so-called 'bullying discourse' the intensification of which we have witnessed in the last few decades. Although discourse on bullying and its focus on peer-to-peer violence is surely relevant as it helps make visible the practices of marginalization and exclusion young LGBTIQ+ are facing, it is also important, as some authors emphasize, to acknowledge the limits of reducing the experience of violence and/or discrimination on the basis of gender and sexual identity within education with regard to the 'bullying discourse'. Namely, this reduction may result in neglect of institutional characteristics that function in a way which legitimizes peer-to-peer violence by their heteronormative and cisnormative structures, as well as in the neglect of school workers' contributions to such experiences - not only their contribution 'in silence', that is, by failing to intervene when bullying happens, but also by actively legitimizing and engaging in such practices of violence (Payne, Smith, 2012; Formby, 2015).

Moreover, focusing on violence in education in terms of 'bullying discourse' tends to read violence as a result of individual and/or family pathology, reinforcing the binary schema of bully - victim without sufficient attention being paid to social power relations, social categorizations and their boundary-making enactment through regulatory and disciplinary practices in everyday life (Bansel, Davies, Laws, Linnell, 2009). In this regard, various forms of violence within education should be approached within a wider context of power relations, including the hetero- and cisnormative structuring ${ }^{1}$ of education that is evident by various practices of discrimination and

1 Heteronormativity can be broadly defined as social structures, privileging heterosexuality while deprivileging various and non-straight sexual identities (Berlant, Warner, 1998). Cisnormativity 
violence, as well as by the absence or at least a lack of systematic presence (that exceeds a format of one-time lectures) of LGBTIQ+ related topics (MacIntosh, 2007). When the issue of violence against LGBTIQ+ individuals is approached in this way, education can be problematized as one of the mechanisms, maintaining and reproducing existing power relations and inequalities based on gender and sexuality, including for example the education functioning as a mechanism of normative-gendered and (hetero)sexually-based socialization, as evident from gender-based incentives (i.e. for creativity when it comes to boys and diligence when it comes to girls) (Mencin Čeplak, Tašner, 2009) to practices of violence targeting those who 'deviate' from normative gender (including gender roles and gender expressions) and sexual identities (Takács, 2006; Mencin Čeplak, 2009; DePalma, Jennett, 2010; Ringrose, Renold, 2010; Mencin Čeplak, 2013). Therefore, practices that exert violence in a non-symbolic way should be understood as derived from social (cisnormative and heteronormative) structures, structuring the field of education.

As emphasized by Ringrose and Renold (2010; also Takács, 2006), violence against LGBTIQ+ people should be addressed as a mechanism of 'gender-policing' that is central for the production of 'normative' ways of doing gender and is part of what Butler (1990) names a 'heterosexual matrix' in which 'biological' sex (male, female) is equated with gender (in terms of gender roles and gendered as well as gendering practices, that is, masculinity and femininity) and heterosexual desire. In this regard, 'failure' to 'successfully' enact normative gender roles is read as a sign of one's homosexuality, which shows intertwinement of violence on the grounds of one's sexual identity and processes of 'gendering', disciplinary practices that enforce normative enactment of assigned gender roles (Takács, 2006).

\subsection{Research overview}

Research on violence against LGBTIQ+ youth is predominantly implemented in relation to young gays and lesbians (e.g. Švab, Kuhar, 2005; Švab, 2016) and less often in relation to various sexual identities, including bisexuality, asexuality, pansexuality, queer, etc., and gender identities, including transgender and cisgender non-normative identities (transgender men, transgender women, gender non-binary, genderqueer, agender, etc.): data on experiences with violence on the basis of these latter identities is thus scarce, especially in relation to the experiences of transgender students (Formby, 2015). ${ }^{2}$

denotes such structures that privilege cisgender people, while deprivileging transgender and cisgender non-normative people, although the use of prefix cis is not without its contradictions (Richardson, Monro, 2012; Stryker, 2017).

2 For example, GLSEN, an organization that every two years implements research on the national (U. S.) school climate in relation to sexual and gender identities started including the question about hearing 
GLSEN's research $(2014 ; 2016)$ in the context of the U. S. shows that more than half of LGBTIQ+ students (55\%) feel unsafe at school because of their sexual identity and $38 \%$ because of their gender expression, and the vast majority have experienced verbal harassment on the basis of their sexual orientation (74\%) and more than half (55\%) because of their gender expression (2014). More than one third of LGBTIQ+ students (36\%) reported being physically harassed in the past year on the basis of their sexual identity and $22 \%$ on the basis of their gender expression (ibid.). GLSEN's latest report (2016) shows that experiences with violence on the grounds of sexual and gender identity are only very slowly decreasing in some areas, i.e. when it comes to experiences with physical harassment on the basis of sexual orientation (27\%) and gender expression (20\%), although the trend of decreasing cannot be generalized to all forms of violence (i.e. being physically assaulted on the basis of sexual or gender identity) (GLSEN 2014; 2016). A report by ILGA-Europe and IGLYO (Takács, 2006) on the social exclusion of young LGBT people shows it is the school environment which is experienced as the most hostile: two thirds of respondents reported having negative experiences on the grounds of their sexual and gender identity in relation to: 1) a curriculum which addressed LGBT topics in a prejudiced or discriminative way (53\%), and 2) bullying (43\%), where most of the respondents reported having experience of verbal attacks. The European Union Agency for Fundamental Rights' report (2014) shows a similar picture: on average and across countries in the European Union, $68 \%$ of respondents reported they rarely, often or always experienced negative comments or conduct at school because of being LGBT (with gays being slightly more exposed to such practices). ${ }^{3}$

In the context of Slovenia, research show that around 35\% of students who identify as gay, lesbian, bisexual or queer experienced violence on the basis of their sexual identity at least once during their education, and more than one out of ten often experiences (mostly verbal) violence (Kuhar, et al., 2008, in Maljevac, Magić, 2009). As emphasized by Slovenian LGBT+ non-governmental organisations, schools are not perceived as a safe space by LGBTIQ+ youth (Magić, Maljevac, 2016, 33): "Backed by political apathy, Slovenian schools are similarly slow in attending to the needs of gay and lesbian youth". As such, education is a space in which topics regarding nonstraight sexualities and non-cisgender identities are more or less absent, or, if present, in the form of one-time lectures that usually receive a severe backlash from local and school communities and civil initiatives (ibid.; Rener, 2009). Research, implemented by DIC Legebitra, shows that even LGBT school workers refrain from introducing the topic of (non-straight) sexual identities due to fear of being perceived as biased

transphobic remarks, such as 'tranny', only from 2013 onward (GLSEN, 2014).

3 Slovenia is placed below the European Union's average (68\%), with $61 \%$ of respondents reporting such experiences on the grounds of their gender and sexual identity (FRA, 2014). 
(Magić, Janjevak 2011). As Rener $(2009,107)$ warns, such silence functions as a form of "spontaneous ideology of homophobia and oppression" that contributes to the socially delegitimized and marginalized status of LGBTIQ+ people. As emphasized by Magić and Maljevac (2016), the socially marginalized status of the LGBTIQ+ community and homophobia (as well as transphobia) are often not recognized as such. Rather, they are seen by national institutions as "a phenomena, a social construct invented by gay activists" (ibid., 42).

The latest research that included the topic of young LGBTIQ+ people's experiences in education, Everyday life of young LGBTIQ+ people, was implemented by Pride Association in 2017 (Perger, Muršec, Štefanec, 2017). Whereas Magić and Maljevac $(2016,31)$ recognize that the research implemented by DIC Legebitra throughout 2008-2013 mostly captures the experiences of gays and lesbians, due to a lack of responses from transgender people, Pride Association's research (2017) succeeded in securing responses from various LGBTIQ+ subgroups, including transgender people and those who identify with various sexual identities that transcend the sexual binary of heterosexual - gay/lesbian. It is these results that are presented below, with special attention given to young LGBTIQ+ people's experiences with violence and discrimination in relation to their peers, teachers and other school workers, including counsellors, and LGBTIQ+ youth's feelings of un/safety in educational settings.

\section{Young LGBTIQ+ experiences with violence in education}

Research Everyday life of young LGBTIQ+ people (Perger, Muršec, Štefanec, 2017) was implemented by the Slovenian Pride Association throughout 2017 (FebruaryOctober) in the context of a wider project that aimed to facilitate a structured dialogue between young LGBTIQ+ people and relevant stakeholders with institutional power to implement the needed changes as identified by young LGBTIQ+ individuals themselves. ${ }^{4}$ The survey, in which youth who self-identify as LGBTIQ+ and are between 16-30 years of age participated, represented the first phase of a project in which the experiences of LGBTIQ+ youth with discrimination and/or violence in various settings (ranging from education and health system, public spaces to families of origin) were analysed, which served as the basis for the second phase in which concrete demands were formulated by LGBTIQ+ people and presented to the relevant stakeholders in the third and final phase of the project (ibid.). Altogether, 751 young LGBTIQ+ people participated in a survey that was disseminated through Slovenian LGBTIQ+ organizations and youth organizations, as well as through social media (ibid.). 
Most of the respondents (66\%) currently reside in the two largest cities in Slovenia (Ljubljana, Maribor). In terms of their age, the majority (64\%) are between 18 and 26 years of age, and the majority (71\%) were assigned female at birth, 28\% assigned male at birth, and $1 \%$ was born intersex. In terms of their gender identity, the majority (59\%) identify as a woman, $28 \%$ as a man, while the rest identify with gender identities such as gender fluid (3\%), gender non-binary (3\%), gender neutral $(2 \%)$, genderqueer (1\%), agender (1\%) and as transgender $(2 \%) .{ }^{5}$ In terms of their sexual identity, $28 \%$ identify as lesbians, followed by bisexual persons (27\%) and gays (22\%), while the rest identify with sexual identities such as pansexual (9\%), queer (4\%), heterosexual (6\%) and asexual (2\%). In the following sections, we are focusing on their experiences with violence and/or discrimination on the basis of their gender and sexual identities within education in relation to their 1) peers, and 2) teachers and other school workers, including counsellors. Such experiences were captured in closed form questions with an option of giving more elaborated answers as well (Perger, Muršec, Štefanec, 2017).

\subsection{Young LGBTIQ+ individuals' experiences with peer-to-peer and school workers' violence}

Research (Perger, Muršec, Štefanec, 2017) shows that 43\% of LGBTIQ+ youth openly identify as LGBTIQ+ in relation to their schoolmates, $40 \%$ of respondents said they had partly come out as LGBTIQ+, while $18 \%$ of respondents completely hid their LGBTIQ+ identities. Approximately two thirds of respondents (65\%) feel their gender and sexual identity is fully accepted by their schoolmates, which makes such relationships one of the most accepting ones, beside friendships (in which $83 \%$ of LGBTIQ+ youth feel completely accepted) and relationships with their siblings (in which $68 \%$ of respondents feel completely accepted). Less than one out of ten respondents (7\%) feel their gender and sexual identity is completely rejected by their schoolmates. In comparison to schoolmates, respondents are much more selective when it comes to disclosing their gender and sexual identity to school workers. Namely, only $13 \%$ of LGBTIQ+ youth are completely out to their teachers, $10 \%$ to other school workers (such as counsellors, principals, etc.), while the majority remain completely closeted: 53\% of LGBTIQ+ students did not disclose their sexual and gender identity to teachers, and $65 \%$ did not do so to other school workers. Almost a fifth of those that are at least in some degree out in relation to teachers (17\%) and other school workers (18\%) feel their gender and sexual identity is completely rejected by these individuals. As Beemyn and Rankin (2011) emphasize, the level of outness and a selective approach to coming out can serve as a strategy of protection, where one discloses one's gender and sexual identity to those from whom one can expect at least

5 This does not mean there were $2 \%$ of transgender respondents, as some may choose gender category of a man or a woman rather than the category 'transgender person'. 
neutral, if not accepting, legitimizing reaction, although for some transgender people such a strategy is unavailable (i.e. if they are in the gender confirmation process). In this regard, research shows that (almost) half of LGBTIQ+ participants sometimes or often hid their gender and sexual identity to avoid potential violence and/or discrimination from teachers (49\%) and other school workers (43\%), while for others disclosing their sexual and gender identity may not seem relevant due to their perceived intimate and private character (Perger, Muršec, Štefanec, 2017).

When it comes to young LGBTIQ+ individuals' experiences with violence and/or discrimination, school is a place marked with one of the highest degree of violence. On a general level, $40 \%$ of respondents have experienced violence on the basis of gender and/or sexual identity, and 29\% experienced violence and/or discrimination in education. In this regard, the level of experiencing violence and/ or discrimination in school settings is similar to that of public places, such as streets, where $39 \%$ of LGBTIQ+ youth have already experienced violence and discrimination (in comparison with violence within the family of origin, where $22 \%$ of respondents reported such experiences). In terms of experiencing violence on the basis of sexual identity, gays are most often exposed to violence in the context of school hallways. Namely, $71 \%$ of gays sometimes and often experience such violence in comparison to bisexuals (40\%), lesbians (40\%) and pansexuals (25\%): only $12 \%$ of gays have never experienced violence in school hallways. In terms of experiencing violence on the basis of non-normative (non-cis) gender identity, $11 \%$ of gender neutral persons $(n=5)$ and $11 \%$ of transgender persons $(n=8)$ sometimes and often experience violence in this context. When it comes to experiencing violence on the basis of sexual identity in the classroom, $70 \%$ of gays reported they sometimes and often experience violence, followed by lesbians (42\%), bisexuals (41\%) and pansexuals (22\%); in terms of nonnormative gender identity, $13 \%$ of gender neutral persons $(n=4)$ and $13 \%$ transgender persons $(n=4)$ reported they sometimes and often experience violence in classrooms. (ibid.)

Despite the high level of acceptance by their schoolmates, $28 \%$ of respondents reported that the perpetrators of all forms of violence they have experienced were their schoolmates, while 5\% $(n=24)$ reported teachers and other school workers as the perpetrators. These experiences of violence by with schoolmates as perpetrators, as they are further elaborated upon by respondents in the open answers section, range from delegitimizing practices that attempt to constitute certain identities as nonexistent or fictional: "schoolmates have often told me that I'm just pretending to be a bisexual", to experiences with verbal harassment and physical violence: "a schoolmate has often verbally harassed me, at some point he even burnt my hand with a lighter"

6 All responses are translated by the author. 
and "insults, just the same as on the streets, pushing me into the lockers, locking me in the toilet, bullying". Experiences with de-legitimization practices are perhaps more common when it comes to sexual identities that transcend dominant sexual binary of heterosexual - gay/lesbian identities: as shown by numerous authors, bisexuality, but also other non-monosexual identities, are targeted with such practices that render them invisible by constituting them as a phase in an otherwise presumably linear trajectory of developing a 'homosexual' identity and as a phase of experimenting (Fahs, 2009; Monro, 2015; Flanders, Robinson, Legge, Tarasoff, 2016; Flanders, Lebreton, Robinson, Bian, Caravaca-Morera, 2017).

Young LGBTIQ+ individuals who participated in the research (Perger, Muršec, Štefanec) also reported that some schoolmates started to avoid them when they disclosed their sexual identity because of their assumptions that a non-straight student will be attracted to them:

My schoolmates were saying that it is inappropriate and extremely weird. They have started to avoid me, telling me they will not hang out with me anymore, because they thought I liked them.

In other cases, such assumptions based on prejudice can even lead to sexual harassment accusations against non-straight students, forcing them to constantly self-discipline and self-regulate when it comes to expressions of affection with their friends, and to the spill-over effect of stigma, where the LGBTIQ+ identity of one stigmatizes their social network as well:

I was often insulted as 'being abnormal, because I am a lesbian' and the same schoolmates have accused me of sexual harassment when I hugged my friends. Consequently, I have started to avoid physical contact with my friends, because then they too were accused of being abnormal.

Others have also reported being sexually attacked by their schoolmates: "Insulting remarks in school. In gimnazija ${ }^{7}$, when we were at the pool, someone shoved a finger in my anus". According to GLSEN's report (2016), almost $60 \%$ of LGBTIQ+ students were sexually harassed (in terms of unwanted touching, sexual remarks) in the year prior to the survey. Given the reported experience above, sexual harassment can be seen as a form of gender policing encompassing policing of hegemonic masculinity and normative femininity (DePalma, Jennett, 2010; Connell, 2012). Both are heterosexualized, or, "disciplined into heterosexuality" (Connell, 2012, 152) and when social processes of heterosexualization visibly 'fail' (in terms of non-normative

7 Gimnazija is a 4-year programme of general upper secondary education. Students finish the programme with the general matura exam, which enables them to apply directly to university. Gimnazija is commonly considered as the most prestige type of upper secondary education in Slovenia, enrolling academically most successful students (Gaber, 2006; Taštanoska, 2017). 
gender expression, i.e. feminized gay, masculinized lesbian, etc.), the 'failure' of nonstraight men, especially gays, to enact hegemonic masculinity is 'made clear' by sexual harassment practices that render and constitute them as inferior by relating to them as a feminized sexual object: through his sexuality, his gender status is questioned (Jackson, 2006).

In education, transgender people are faced with some unique issues with regard to their identity being recognized, accepted and legitimized through practices in everyday life, such as using the correct pronouns and name - one that is differently gendered from that they were assigned at birth: Beemyn and Rankin (2011) show that $27 \%$ of transgender respondents reported experiencing harassment in the past year because of their gender identity and/or expression, with female-to-different gender participants and male-to-different gender participants ${ }^{8}$ reporting such experiences in slightly higher proportions. McLemore (2015) warns that misgendering practices (practices of non-/mis-recognition of one's gender) are associated with negative affect, less identity strength and coherence and more felt stigma - and the use of wrong gender terms tends to diminish a transgender person's self-respect (Kapusta, 2016). Given the limitations of gender identity expression and gendering practices, deriving from the dominant gender binary as it is manifested in everyday life (including gendered language, gender binary toilets, gender-segregated P.E. classes, etc.), gender nonbinary students are faced with even more challenges (Beemyn, 2015). In this regard, a respondent reported schoolmates' consistent failure to respect his gender identity when he came out as a transgender person:

It was in high school that I came out as $\mathrm{FTM}^{9}$ and the majority of my schoolmates turned their backs on me, giving me wrong school notes, using the wrong pronouns, despite me constantly and politely correcting them. I understand it is hard to get used to it, but this lasted for a few years and now, when I am studying at the faculty, the same is happening from those same people.

In relation to violence and/or discrimination perpetrated by school workers, young LGBTIQ+ individuals reported 'lectures', given by teachers, delegitimizing the existence of transgender and non-normative cis-gender identities, constituting them as 'ideological' and fictional and framing them as 'gender theory':

8 Beemyn and Rankin (2011) use 'female-to-different-gender' and 'male-to-different-gender' to name those respondents who do not identify neither as a woman nor as a man, while acknowledging the social importance attached to specific embodiment (seen as female or a male) that frames social recognition processes, and to gender assigned at birth, deriving from a specific form of embodiment, and their role in production of violence, targeting transgender people.

$9 \quad$ FTM (female to male) denotes a person that was assigned female at birth and who identifies as a man. 
Lectures about how 'gender theory' is fictional and that transgender and non-binary identities do not exists, and that marriage equality, should not be allowed were regularly on the school agenda. There were insults from teachers as well as from schoolmates.

This phenomenon is in parallel with Europe-wide trends of anti-gender campaigning and mobilizing against gender equality, as identified by Kuhar and Patternote (2017).

Participants in the research Everyday life of young LGBTIQ+ individuals (Perger, Muršec, Štefanec, 2017) also reported explicit attempts from teachers to discipline them into normative sexual (and thus, gender) roles with threats of being excluded from school: "One professor threatened that she will do anything to get me excluded from school if I do not break up with my girlfriend", while others reported that there were disciplinary reports made against them due to their 'inappropriate behaviour': "My class teacher told me she received an appeal by another teacher because of mine and my girlfriend's expressions of affection", and "One of the teachers made an appeal against the inappropriate behaviour of me and my girlfriend". These findings are comparable to those of GLSEN's report (2014), where 28\% of LGBTIQ+ students reported being disciplined for public displays of affection. In some cases, experiences with violence forced LGBTIQ+ students to change schools: "All these things were so annoying that I was forced to change school". Violence, perpetrated by school workers, is often a neglected part of LGBTIQ+ individuals' experiences with violence in education. Such neglect manifests in a discourse of violence in education, often reduced to a 'bullying' discourse that mostly focuses and problematizes peer-to-peer violence, therefore excluding the heteronormative and cisnormative structuring of education from the analysis (Payne, Smith, 2018). Although school workers, alongside family members, peers and youth services agencies, are identified as an important part of the supporting infrastructure, in reality their support is usually lacking (Marshall, Yarber, Sherwood-Laughlin, Gray, Estell, 2015).

Both violence perpetrated by school mates and by school workers should be understood in the wider social context, taking into account social structures and the world of adults which "legitimizes violence by various forms of discrimination and Othering” (Razpotnik, Dekleva, 2015, 218; Muršič, 2012). Heteronormativity and cisnormativity as social structures translate into 'organizational structures' in schools, legitimizing homophobia, biphobia, transphobia and other practices of delegitimizing and marginalizing non-straight and non-cisgender, non-normative gender identities and expressions, maintaining "existing power relations" with their homophobic and misogynistic discourses "depend[ing] on an implicit consensus" (DePalma, Jennett, 
2010, 18). Drawing from Bourdieu $(1998,40)$, heteronormativity and cisnormativity should be approached as forms of structural violence that - similar to the structural violence of the dominant economy to which Bourdieu primarily refers - are paid for in "a whole host of minor and major everyday acts of violence". Education is one of the primary mechanisms that ensure the reproduction of social order, including masculine domination and also encompassing gendered libido (Bourdieu, 2010), in relation to which non-straight sexual and non-normative gender identities represent a 'deviation' from the dominant - "always sexually overdetermined" - androcentric principle (ibid.). Its transmission runs through diffuse pedagogic action, enacted by the whole group and a "whole symbolically structured environment" (Bourdieu, 2005, 90). As such, hetero- and cis-normativity function as forms of symbolic domination through processes of categorizing, establishing classes (ibid.), the boundaries of which are anonymously, subtly maintained, but also forcibly guarded when threatened by those who threaten to destroy the (heterosexualized and normatively gendered) game - as we can see, education and its agents are not an exception in this regard.

\section{Concluding remarks}

When education is recognized as an institution, reproducing wider social inequalities on various axes, including those of gender and sexuality, with its mechanisms of reproduction, including production of different forms of violence, that often remain invisible, silent and non-recognized as such (Bourdieu, 2010), it is not surprising that LGBTIQ+ students do not perceive school as a safe space. More specifically, $27 \%$ of LGBTIQ+ students sometimes or often fear for their safety in the context of school hallways, $17 \%$ sometimes or often fear for their safety in classrooms, $8.5 \%$ in relation to their teachers, and $8 \%$ in relation to other school workers (Perger, Muršec, Štefanec, 2017), which shows that "the world extends the form of some bodies more than others" (Ahmed, 2006, 129), that is, the world allows and shapes certain bodies to feel more 'at home' than others, while at the same time it is shaped by certain bodies more than others and it shapes those 'others' as 'strangers', as being dislodged (ibid.), or, put differently, it shapes their sense of (their) place as being out-of-place (Bourdieu, 2000, 184). Violence as exerted by school workers and schoolmates is violence made explicit in an attempt to maintain and guard normativity, threatened and destabilized by those 'not-at-home', who disclose its unquestioned, naturalized status as arbitrary by their existence in a space - this time, education - that was not meant to accommodate them, and, even more, that was meant to ensure such shaping of 'bodies' that would exclude 'out-of-placeness' as a place 'legitimately' deserved and reserved for some from being questioned. 
Such violence is not derived from agents in education themselves, rather, it is derived from relations between them and a specific hetero- and cis-normative structuring of education, which means that various forms of intervention programmes that attempt to address the issues of violence and discrimination of LGBTIQ+ students will not be effective enough in the long run unless they recognize and address wider issues of power relations that structure the 'inside' of education (Herr, Anderson, 2003; MacIntosh, 2007; Bansel, Davies, Laws, Linell, 2009; Payne, Smith, 2012). Otherwise, such intervention programmes, usually grounded in the 'bullying discourse', which often individualise the problem of bullying, turning it into an individual pathology, a problem of individual maladjustment, will 'merely' function as a 'band-aid' (MacIntosh, 2007, 36). Something more is needed, starting with the acknowledgement of the role schools play in producing such violence, that is, from the recognition of their nonneutral role in re-producing wider social inequalities, a recognition that closes down the possibility of education to be exempted from potential calling-out and bearing of responsibility when it comes to violence against LGBTIQ+ students.

\section{Bibliography}

Ahmed, S., Queer phenomenology, Durham, London 2006.

Bansel, P., Davies, B., Laws, C., Linnell, S., Bullies, bullying and power in the contexts of schooling, British Journal of Sociology of Education 1, 30, 2009, pp. 59-69.

Beemyn, G., Coloring Outside the Lines of Gender and Sexuality: The Struggle of Nonbinary Students to Be Recognized. The Educational Forum 4, 79, 2015, pp. 359-361.

Beemyn, G., Rankin, S., The lives of transgender people, New York 2011.

Berlant, L., Warner, M., Sex in public, Critical inquiry 2, 24, 1998, pp. 547-566.

Bourdieu, P., Acts of resistance: Against the new myths of our time, Cambridge 1998.

Bourdieu, P., Pascalian meditations, Stanford 2000.

Bourdieu, P., Belief and the body, in: The body: A reader (ed. Fraser, M., Greco, M.), Oxon 2005, pp. 87-91.

Bourdieu, P., Moška dominacija, Ljubljana 2010.

Butler, J., Gender trouble: Feminism and the subversion of identity, New York 1990.

Connell, R., Moškosti, Ljubljana 2012.

DePalma, R., Jennett, M., Homophobia, transphobia and culture: deconstructing heteronormativity in English primary schools, Intercultural Education 1, 21, 2010, pp. 15-26. 
Fahs, B., Compulsory bisexuality?: The challenges of modern sexual fluidity, Journal of bisexuality 3/4, 9, pp. 431-449.

Flanders, C. E., Robinson, M., Legge, M. M., Tarasoff, L. A., Negative identity experiences of bisexual and other non-monosexual people: A qualitative report, Journal of gay \& lesbian mental health 2, 20, 2016, pp. 152-172.

Flanders, E. C., Lebreton, E. M., Robinson, M., Bian, J., Caravaca-Morera, J. A., Defining bisexuality: Young bisexual and pansexual people's voices, Journal of bisexuality 1, 17, 2017, pp. 39-57.

Formby, E., Limitations of focussing on homophobic, biphobic and transphobic 'bullying' to understand and address LGBT young people's experiences within and beyond school, Sex Education 6, 15, 2015, pp. 626-640.

FRA - European Agency for Fundamental Rights. EU LGBT Survey: European Union lesbian, gay, bisexual and transgender survey, Luxembourg 2014.

Gaber, S., Edukacija, socialna promocija in »dedovanje« izobrazbe. Sodobna pedagogika, posebna izdaja, 2006, pp. 42-53.

GLSEN, The 2013 National School Climate Survey: The experiences of Lesbian, Gay, Bisexual and Transgender Youth in Our Nation's School, New York 2014. https:// www.glsen.org/sites/default/files/2013\%20National\%20School\%20Climate\%20 Survey\%20Full\%20Report_0.pdf [4. 5. 2017].

GLSEN, The 2015 National School Climate Survey: The Experiences of Lesbian, Gay, Bisexual, Transgender, and Queer Youth in Our Nation's Schools, New York 2016. https://www.glsen.org/sites/default/files/2015\%20National\%20GLSEN\%20 2015\%20National\%20School\%20Climate\%20Survey\%20\%28NSCS\%29\%20-\%20 Full\%20Report_0.pdf [4.5.2017].

Herr, K., Anderson, G., Violent youth or violent schools? A critical incident analysis of symbolic violence, Int. J. Leadership in Education 4, 6, 2003, pp. 415-433.

Jackson, S., Gender, sexuality and heterosexuality: The complexity (and limits) of heteronormativity, Feminist Theory 1, 7, 2006, pp. 105-121.

Kapusta, J. S., Misgendering and its moral contestability. Hypatia 3, 31, 2016, pp. 502519.

Kuhar, R., Patternote, D. (ed.), Anti-gender campaigns in Europe: Mobilizing against equality, London, New York 2017.

MacIntosh, L., Does anyone have a Band-aid? Anti-homophobia discourses and pedagogical impossibilities, Educational studies 1, 41, 2007, pp. 33-43.

Magić, J., Janjevak, A., "Excuse me, Miss, are you a lesbian?" A research report on the situation of LGBT educational workers in the school system in Slovenia, Ljubljana 
2011. https://www.ilga-europe.org/sites/default/files/excuse_me_miss_are_you_a_ lesbian.pdf [4. 5. 2017].

Magić, J., Maljevac, S., Research for action: Challenging homophobia in Slovene secondary education, Journal of LGBT Youth 1-2, 13, pp. 28-45.

Maljevac, S., Magić, J., Pedri raus!: Homofobično nasilje v šolah. Sodobna pedagogika 4, 2009, pp. 90-104.

Marshall, A., Yarber, W. L., Sherwood-Laughlin, C. M., Gray, M. L., Estell, D. B., Coping and survival skills: The Role School Personell Play Regarding Support for Bullied Sexual Minority-Oriented Youth, Journal of School Health 5, 85, 2015, pp. 334-340.

McLemore, K. A., Experiences with misgendering: Identity misclassification of transgender spectrum individuals, Self and Identity 1, 11, 2015, pp. 51-74.

Mencin Čeplak, M., Tašner, V., Spolne neenakosti v izobraževanju, in: Brez spopada: kultur, spolov, generacij, (ed. Tašner, V.), Ljubljana 2009, pp. 103-116.

Mencin Čeplak, M., Spolne/seksualne norme, legitimacija izključevanja in šola, Sodobna pedagogika 4, 2009, pp. 120-132.

Mencin Čeplak, M., Heteronormativity: School, ideology, and politics, Journal of pedagogy 2, 4, 2013, pp. 162-187.

Monro, S., Bisexuality: Identities, politics, and theories, Hampshire, New York 2015.

Muršič, M., Prekiniti krog nasilja (za varnejše družine in vzgojno-izobraževalne zavode, in: (O)Krog nasilja $v$ družini in šoli: Soočanje šole/vrtca $z$ nasiljem nad otroki (ed. Muršič, M.), Ljubljana 2012, pp. 7-41.

Payne, E., Smith, M., Rethinking Safe Schools Approaches for LGBTQ Students: Changing the Questions We Ask, Multicultural Perspectives 4, 14, 2012, pp. 187193.

Payne, E. C., Smith, M. J., Refusing Relevance: School Administrator Resistance to Offering Professional Development Addressing LGBTQ Issues in Schools, Educational Administration Quarterly 2, 54, 2018, pp. 1-33.

Perger, N., Muršec, S., Štefanec, V., Vsakdanje življenje mladih LGBTIQ+ oseb, unpubl., Ljubljana 2017.

Razpotnik, Š., Dekleva, B., Medvrstniško nasilje v šoli - socialnopedagoški pogled, Socialna pedagogika 3-4, 19, 2015, pp. 217-230.

Rener, T., Homoseksualnost in šola: stališča študentk in študentov do obravnavae homoseksualnosti pri pouku, Sodobna pedagogika 4, 2009, pp. 106-119.

Richardson, D., Monro, S., Sexuality, equality \& diversity, Hampshire 2012. 
Ringrose, J., Renold, E., Normative cruelties and gender deviants: the performative effects of bully discourse for girls and boys in school, British Educational Research Journal 4, 36, 2010, pp. 573-596.

Stryker, S., Transgender history: The roots of today's revolution, New York 2017 ( $2^{\text {nd }}$ ed.).

Švab, A., Narratives of coming out to parents: Results of replicating a sociological study on the everyday life of gays and lesbians in Slovenia (2014-2015), Teorija in praksa 6, 53, 2016, pp. 1344-1355.

Švab, A., Kuhar, R., Neznosno udobje zasebnosti: Vsakdanje življenje gejev in lezbijk, Ljubljana 2005.

Takács, J., Social exclusion of young lesbian, gay, bisexual and transgender (LGBT) people in Europe, Brussels, Amsterdam 2006. https://www.ilga-europe.org/sites/ default/files/Attachments/social_exclusion_of_young_lesbian_gay_bisexual_ and_transgender_people_lgbt_in_europe_april_2006.pdf [24. 4. 2017].

Taštanoska, T. (ed.), Vzgoja in izobraževanje $v$ Republiki Sloveniji, 2016/17, Ljubljana 2017. http://www.eurydice.si/images/publikacije/BROSURA-vzgojainizobrazevanje-v-RS-2016-17.pdf [4. 3. 2018]. 


\section{Nina Perger}

\section{LGBTIQ+ mladi in izkušnje z nasiljem na področju edukacije}

Ključne besede: LGBTIQ+, edukacija, nasilje, razmerja moči

$\mathrm{V}$ pričujočem prispevku se osredotočamo na izkušnje mladih gejev, lezbijk, biseksualnih, transspolnih, interspolnih in kvir oseb (LGBTIQ+) v izobraževanju na osnovi raziskave Vsakdanje življenje mladih LGBTIQ+ oseb, ki jo je leta 2017 izvedlo Društvo Parada ponosa. V njej je sodelovalo 751 mladih, starih od 16 do 30 let. Pri tem se osredotočamo na izkušnje $\mathrm{z}$ medvrstniškim nasiljem, pa tudi $\mathrm{z}$ nasiljem in $\mathrm{s}$ praksami (heteroseksualiziranega in cisnormativnega) discipliniranja s strani šolskih delavk_cev. Izkušnje z nasiljem na področju edukacije so sicer pogosto obravnavane $\mathrm{s}$ pomočjo koncepta medvrstniškega nasilja, ki z individualizacijo odgovornosti in obravnavanjem nasilja kot individualnih "patologij« neredko s težavo obravnava pomen hetero- in cisnormativnih družbenih struktur ter njihovih realizacij v povezavi z nasiljem znotraj izobraževalnega konteksta. Prakse nasilja in discipliniranja, usmerjene proti mladim LGBTIQ+ osebam, delujejo kot mehanizem reproduciranja in krepitve omenjenih družbenih struktur, zaradi česar jih je treba za učinkovito obravnavo in naslavljanje izkušenj z nasiljem zaradi nenormativne spolne in seksualne identitete umestiti v širši kontekst družbenih razmerij moči. 


\section{Nina Perger}

\section{LGBTIQ+ Youth and Experiences with Violence in Education}

Keywords: LGBTIQ+, education, violence, power relations

In the article, we focus on young LGBTIQ+ individuals' experiences with violence in education. Research show that LGBTIQ+ youth are targeted with various forms of violence within education; while most research focuses on peer-to-peer violence, the violence perpetrated by school workers, and their inactivity when it comes to addressing violence on the basis of gender and sexual identity, is often neglected. In the article, data gathered in the research Everyday life of young LGBTIQ+ individuals, as implemented by Pride Association in 2017, is presented. A total of 751 young LGBTIQ+ individuals aged between 16-30 participated in this research. In this article we focus on a specific aspect regarding their experiences with violence in education, namely, their experiences with violence perpetrated by schoolmates and school workers, including teachers and counsel workers, as well as on their feelings of safety in the school hallways and classrooms. Such violence is often addressed by 'bullying discourse', which rarely takes into account hetero- and cisnormative social structures and their manifestations in education, and it predominantly addresses bullying as a form of individual pathology and not as practices of violence that derive their disciplinary power in terms of enforcing normative enactments of gender and sexuality. In this regard, violence against young LGBTIQ+ individuals in education should be addressed within a broader framework that takes into account social power relations. 